Article

\title{
Use of a New Non-Pyrophoric Liquid Aluminum Precursor for Atomic Layer Deposition
}

\author{
Xueming Xia ${ }^{1}$, Alaric Taylor ${ }^{2}\left(\mathbb{B}\right.$, Yifan Zhao $^{3}$, Stefan Guldin ${ }^{2}\left(\mathbb{D}\right.$ and Chris Blackman ${ }^{1, *(1)}$ \\ 1 Department of Chemistry, University College London, 20 Gordon Street, London WC1H 0AJ, UK; \\ xueming.xia.16@ucl.ac.uk \\ 2 Department of Chemical Engineering, University College London, Torrington Place, London WC1E 7JE, UK; \\ alaric.taylor@ucl.ac.uk (A.T.); s.guldin@ucl.ac.uk (S.G.) \\ 3 Department of Life Sciences, Imperial College London, South Kensington Campus, London SW7 2AZ, UK; \\ yifan.zhao15@imperial.ac.uk \\ * Correspondence: c.blackman@ucl.ac.uk; Tel.: +44-207-679-4703
}

Received: 2 April 2019; Accepted: 30 April 2019; Published: 2 May 2019

check for updates

\begin{abstract}
An}_{2} \mathrm{Al}_{2} \mathrm{O}_{3}$ thin film has been grown by vapor deposition using different $\mathrm{Al}$ precursors. The most commonly used precursor is trimethylaluminum, which is highly reactive and pyrophoric. In the purpose of searching for a more ideal $\mathrm{Al}$ source, the non-pyrophoric aluminum tri-sec-butoxide $\left(\left[\mathrm{Al}\left(\mathrm{O}^{\mathrm{s}} \mathrm{Bu}\right)_{3}\right], \mathrm{ATSB}\right)$ was introduced as a novel precursor for atomic layer deposition (ALD). After demonstrating the deposition of $\mathrm{Al}_{2} \mathrm{O}_{3}$ via chemical vapor deposition (CVD) and 'pulsed CVD' routes, the use of ATSB in an atomic layer deposition (ALD)-like process was investigated and optimized to achieve self-limiting growth. The films were characterized using spectral reflectance, ellipsometry and UV-Vis before their composition was studied. The growth rate of $\mathrm{Al}_{2} \mathrm{O}_{3}$ via the ALD-like process was consistently $0.12 \mathrm{~nm} /$ cycle on glass, silicon and quartz substrates under the optimized conditions. Scanning electron microscopy and transmission electron microscopy images of the ALD-deposited $\mathrm{Al}_{2} \mathrm{O}_{3}$ films deposited on complex nanostructures demonstrated the conformity, uniformity and good thickness control of these films, suggesting a potential of being used as the protection layer in photoelectrochemical water splitting.
\end{abstract}

Keywords: chemical vapor deposition; atomic layer deposition; aluminum oxide; aluminum tri-sec-butoxide; thin film

\section{Introduction}

As a dielectric metal oxide, $\mathrm{Al}_{2} \mathrm{O}_{3}$ exhibits a high transparency, large bandgap and excellent electrical insulation properties, hence it is widely applied in electronic devices and electrochemistry, e.g., as a protection layer [1-6]. Commonly used methods for making $\mathrm{Al}_{2} \mathrm{O}_{3}$ films include sol-gel, sputtering, evaporation, physical vapor deposition (PVD), chemical vapor deposition (CVD) and atomic layer deposition (ALD) [7-11]. CVD is a widely used thin film deposition technique to provide good quality thin films with control over the chemical composition. ALD uses sequential pulses of precursors which react with the surface in a self-limiting way [12,13], giving better control of material thickness, stoichiometry and conformality than normally afforded via CVD or PVD [14,15].

Careful consideration must be exercised in precursor selection for all vapor deposition processes. Whilst they may be gas, liquid or solid at room temperature, they must be volatile and thermally stable under zationvaporization conditions. Widely used oxygen-containing precursors are $\mathrm{H}_{2} \mathrm{O}, \mathrm{O}_{2}$ and $\mathrm{O}_{3}$, whilst precursors for metals include metal halides, metal alkyls, metal alkoxides, etc [16]. Typical precursors for $\mathrm{Al}$ include aluminum chloride $\left[\mathrm{AlCl}_{3}\right.$ ] [17], trimethylaluminum [TMA, $\left.\mathrm{Al}\left(\mathrm{CH}_{3}\right)_{3}\right]$ [18], aluminum tri-isopropoxide [ $\left.\mathrm{AIP}, \mathrm{Al}\left(\mathrm{O}^{\mathrm{i}} \mathrm{Pr}\right)_{3}\right]$ [19] and aluminum acetylacetonate [ $\left.\mathrm{Al}(\mathrm{acac})_{3}\right]$ [20]. Among 
the above, TMA is the most commonly used $\mathrm{Al}$ precursor, but it is highly reactive, moisture sensitive and pyrophoric, which makes handling inconvenient. The most common non-pyrophoric Al precursor is $\mathrm{Al}\left(\mathrm{O}^{\mathrm{i} P r}\right)_{3}$, but as a solid precursor there is significant possibility of condenzation during vapor transport leading to blockages and consequent reactor downtime. Therefore, in this study, the suitability of aluminum tri-sec-butoxide (ATSB, $\left[\mathrm{Al}\left(\mathrm{O}^{\mathrm{s}} \mathrm{Bu}\right)_{3}\right],\left[\mathrm{Al}\left(\mathrm{OCH}\left(\mathrm{CH}_{3}\right) \mathrm{CH}_{2} \mathrm{CH}_{3}\right)_{3}\right]$ was investigated as an $\mathrm{Al}$ precursor. At room temperature, ATSB is a non-pyrophoric liquid which contains no halogens atoms (Figure 1). ATSB has been previously reported as a metal-organic chemical vapor deposition (MOCVD) precursor [21]. However, to the best of our knowledge, it has never been studied for use in ALD before.

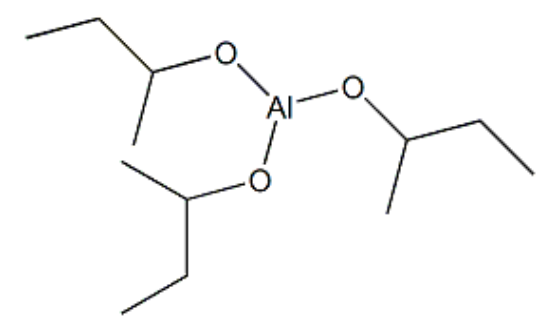

Figure 1. The structural formulas of aluminum tri-sec-butoxide.

In this research, ATSB was used in single-source CVD (also in 'pulsed CVD' mode) and ALD to deposit $\mathrm{Al}_{2} \mathrm{O}_{3}$ thin films. The deposition parameters (precursor temperature, deposition temperature, carrier gas flow rate, pulse time and purge time) were optimized on different substrates to demonstrate controllable and uniform film deposition.

\section{Materials and Methods}

\subsection{Chemicals and Materials}

Aluminum tri-sec-butoxide (ATSB, 97\%) was purchased from Sigma-Aldrich (St. Louis, MI, USA). Propan-2-ol (laboratory reagent grade), methanol (HPLC grade) and ethanol absolute (HPLC grade) were received from Fisher Scientific (Loughborough, UK). Super premium glass microscope slides were purchased from VWR International, LLC (Radnor, PA, USA). Quartz slides were obtained from Wuxi Crystal and Optical Instrument Co., Ltd (Wuxi, China). P-doped silicon wafers were bought from Suzhou Crystal Silicon Electronics \& Technology Co., Ltd (Suzhou, China). Deionized water was obtained from ELGA Purelab Option (ELGA LabWater). Liquid nitrogen and argon gas were provided by the BOC group (Surrey, UK).

\section{2. $\mathrm{Al}_{2} \mathrm{O}_{3}$ Thin Film Deposition via $\mathrm{CVD}$}

Aluminum tri-sec-butoxide (maintained at $120^{\circ} \mathrm{C}$ ) was used as a single-source CVD precursor. ATSB vapor was carried to the reaction chamber via Ar carrier gas. To operate in CVD mode, the inlet valve and outlet valve of the ATSB bubbler were kept open for the entire deposition and no water co-reactant was used. The ATSB bubbler was heated to $115^{\circ} \mathrm{C}, 120^{\circ} \mathrm{C}, 125^{\circ} \mathrm{C}$, respectively. The gas flow rate was set to $150 \mathrm{sccm}$. The substrate was heated to $300^{\circ} \mathrm{C}, 350^{\circ} \mathrm{C}$ or $400^{\circ} \mathrm{C}$ for film deposition. Each deposition took 24 hours. A deposition mode called 'pulsed CVD' was used to mimic the metal precursor half cycle in ALD. A cycle in pulsed CVD mode only contained one ATSB pulse (20 s or $1 \mathrm{~min}$ ) and one argon purge ( $1 \mathrm{~min})$. For all experiments, the pipework was heated to $170^{\circ} \mathrm{C}$ to prevent precursor condenzation.

\section{3. $\mathrm{Al}_{2} \mathrm{O}_{3}$ Thin Film Deposition via ALD}

$\mathrm{Al}_{2} \mathrm{O}_{3}$ films were grown via ALD between 250 and 1000 deposition cycles. ATSB (maintained at $120{ }^{\circ} \mathrm{C}$ ) and deionized water (maintained at $5^{\circ} \mathrm{C}$ ) were held in bubblers as precursors and the precursor vapor was carried to the reaction chamber via Ar carrier gas. Each cycle consisted of an ATSB pulse (2.5-20 s), an argon purge (1-3 min), then followed by a $2 \mathrm{~s}$ water vapor pulse and an argon 
purge of at least $3 \mathrm{~min}$. It is worth noting that the minimum dose time in this reactor is $2 \mathrm{~s}$, which inevitably requires longer purge times than normally observed in an ALD reaction. The gas flow rate through the ATSB bubbler and through the purge line was set to $120 \mathrm{sccm}$. The substrate was heated to $200{ }^{\circ} \mathrm{C}, 250{ }^{\circ} \mathrm{C}, 300{ }^{\circ} \mathrm{C}$ or $350^{\circ} \mathrm{C}$ for film deposition, respectively. Glass, quartz and silicon substrates were used for the comparative study of film growth and quality. $\mathrm{Al}_{2} \mathrm{O}_{3}$ films of different thickness (20-300 cycles) were also deposited on $\mathrm{Au} \mathrm{NPs} / \mathrm{WO}_{3} \mathrm{NRs}$ system to demonstrate uniformity.

\subsection{Characterization}

The thickness of the films was measured using a Variable Angle Spectroscopic Ellipsometer (VASE, SEMILAB SE-2000, Semilab, Budapest, Hungary) in the wavelength range of $1.25-5 \mathrm{eV}$ with variable measuring angle $\left(56^{\circ}, 57^{\circ}, 58^{\circ}, 59^{\circ}\right.$ and $\left.60^{\circ}\right)$. The optical model used for ellipsometric characterization of the ALD-like thin films was an effective medium approximation (EMA) comprising of air and the aluminum oxide (previously reported refractive index) with variable concentration [22,23]. Glass substrates were modelled using standard parameters for sodlime glass and the silicon substrates were assumed to have a $1 \mathrm{~nm}$ native oxide. Fittings of the ellipsometric data converged without the need for substrate-film and film-air diffusion layers. The crystalline structure of the samples was examined by X-ray diffraction (XRD, Bruker, Billerica, MA, USA, D8 Discover LynxEye) with a current of $40 \mathrm{~mA}$ and a voltage of $40 \mathrm{kV}$. The data was collected with a scanning rate of $0.05^{\circ} / \mathrm{s}$ over a $2 \theta$ range from $10^{\circ}$ to $66^{\circ}$ counted at $2 \mathrm{~s}$ per step. X-ray photoelectron spectroscopy (XPS, Thermo Fisher Scientific, Waltham, MA, USA, Neslab ThermoFlex1400) with a monochromatic Al K $\alpha$ X-ray source was used to measure the elemental composition and electronic states of the elements. Tapping mode atomic force microscopy (AFM, Bruker, Billerica, MA, USA, Dimension FastScan2-SYS) using a NCLR tip was employed to investigate the surface structure of the sample. The morphologies of the samples were observed by field emission scanning electron microscope (FESEM, JEOL, Tokyo, Japan, JSM-7800F) with a current of $10 \mathrm{~mA}$ and an acceleration voltage of 5-15 kV after Au coating. Films deposited on $\mathrm{Au} / \mathrm{WO}_{3}$ films and were examined by transmission electron microscopy (TEM, JEOL, Tokyo, Japan, JEM-2100) after they were sonicated in methanol and dropped on copper grids to show the details. Photoelectrochemical (PEC) measurement was carried out using a homebuilt PEC system with a Xe lamp (75W, USHIO, California, USA) equipped with an AM 1.5 G filter (Newport, California, USA) using a Pt mesh counter electrode, a $\mathrm{Ag} / \mathrm{AgCl}$ reference electrode and $\mathrm{Na}_{2} \mathrm{SO}_{4}$ electrolyte. All the photoelectrochemical tests were performed using a potentiostat (Interface 1000, Gamry, Pennsylvania, USA).

\section{Results and Discussion}

\subsection{Deposition Parameter Optimization for CVD}

Aluminum sec-butoxide $\left(\left[\mathrm{Al}\left(\mathrm{O}^{\mathrm{s}} \mathrm{Bu}\right)_{3}\right]\right)$ is a high viscosity liquid metal alkoxide, typically preferred for $\mathrm{CVD}$ reactions in comparison to solid precursors such as $\mathrm{Al}\left(\mathrm{O}^{\mathrm{i}} \mathrm{Pr}\right)_{3}$. The vapor pressure of $\mathrm{ATSB}$ at different temperatures was calculated based on data from literature [24,25] (Figure S1). Note that the function of vapor pressure in the Antoine equation is fitted as $\lg$ (PTorr) $=10.16-4177.25 / \mathrm{T}$.

According to our previous study [26], a metal precursor vapor pressure higher than 0.13 Torr would generate enough metal precursor vapor in our reactor for one pulse. Therefore, a temperature above $115^{\circ} \mathrm{C}$ would provide sufficient vapor pressure.

Initial experiments focused on optimizing the precursor temperature, gas flow rate and deposition temperature for CVD deposition. After several attempts at $115^{\circ} \mathrm{C}, 120^{\circ} \mathrm{C}$ and $125^{\circ} \mathrm{C}$, the optimum ATSB bubbler temperature was found to be $120^{\circ} \mathrm{C}$. Meanwhile, increasing the precursor temperature further did not produce any significant increase in thickness at a deposition temperature of $350{ }^{\circ} \mathrm{C}$ (additional precursor not utilised in deposition). The composition of the films was analyzed by XRD, Raman spectroscopy (inVia Raman microscope, Renishaw, Gloucestershire, UK) and XPS. The crystallization temperature of $\gamma-\mathrm{Al}_{2} \mathrm{O}_{3}$ is at least $600{ }^{\circ} \mathrm{C}$ and $1000{ }^{\circ} \mathrm{C}$ is needed for it to transform 
to $\alpha-\mathrm{Al}_{2} \mathrm{O}_{3}$ [27-29]. As the deposition temperature here was much lower than the crystallization temperature of $\mathrm{Al}_{2} \mathrm{O}_{3}$, it is consistent that neither XRD patterns nor Raman spectra showed pronounced peaks (Figures S2 and S3). For a film deposited at $400{ }^{\circ} \mathrm{C}$ for $24 \mathrm{~h}$ with $120{ }^{\circ} \mathrm{C}$ ATSB precursor temperature and $150 \mathrm{sccm}$ gas flow, the $\mathrm{Al} 2 \mathrm{p}$ spectrum (Figure 2a) displayed an intense peak for the $\mathrm{Al} 2 \mathrm{p}$ ionization at $73.6 \mathrm{eV}$ which matches with the binding energy of $\mathrm{Al}^{3+}$ in $\mathrm{Al}_{2} \mathrm{O}_{3}$ [30]. The $\mathrm{Si} 2 \mathrm{p}$ peak is of very low intensity (Figure $2 b$ ), which indicates that no Si from the glass substrate is observed, thus the $\mathrm{Al}_{2} \mathrm{O}_{3}$ film covers the entire area of the analysis spot. These findings are consistent with the films deposited via CVD using ATSB as a single-source precursor as an amorphous $\mathrm{Al}_{2} \mathrm{O}_{3}$.
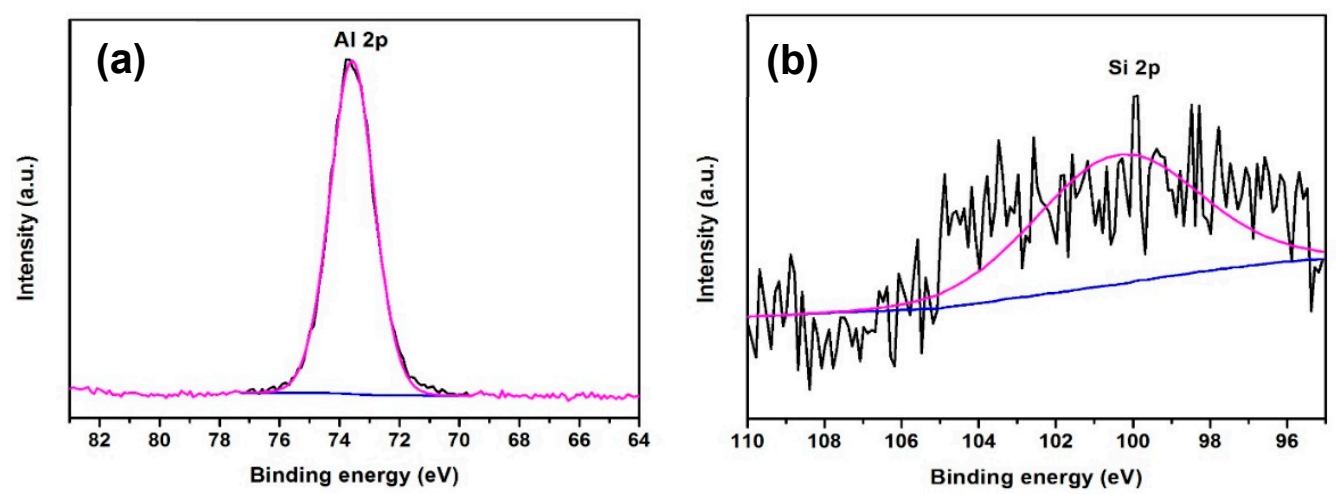

Figure 2. High resolution XPS spectra of (a) $\mathrm{Al} 2 \mathrm{p}$ and (b) Si $2 \mathrm{p}$ of $\mathrm{Al}_{2} \mathrm{O}_{3}$ film deposited on glass via CVD.

To observe the effect of substrate temperature, the CVD deposition temperatures were set to $300{ }^{\circ} \mathrm{C}, 350{ }^{\circ} \mathrm{C}$ and $400{ }^{\circ} \mathrm{C}$ (with a bubbler temperature of $125^{\circ} \mathrm{C}$ ). AFM scans (Figure 3) show an increase in the roughness of film surface as deposition temperature increases; $R_{\mathrm{q}}\left(300^{\circ} \mathrm{C}\right)=3.45 \mathrm{~nm}$, $\mathrm{R}_{\mathrm{q}\left(350^{\circ} \mathrm{C}\right)}=3.76 \mathrm{~nm}$ and $\mathrm{R}_{\mathrm{q}\left(400^{\circ} \mathrm{C}\right)}=18.21 \mathrm{~nm}$, which can also be seen in SEM images (Figure 3). Increasing the deposition temperature increases film roughness, which is typically unfavorable for protective coatings. Consequently, we concluded that $350{ }^{\circ} \mathrm{C}$ provided a good balance between growth rate and surface roughness. 

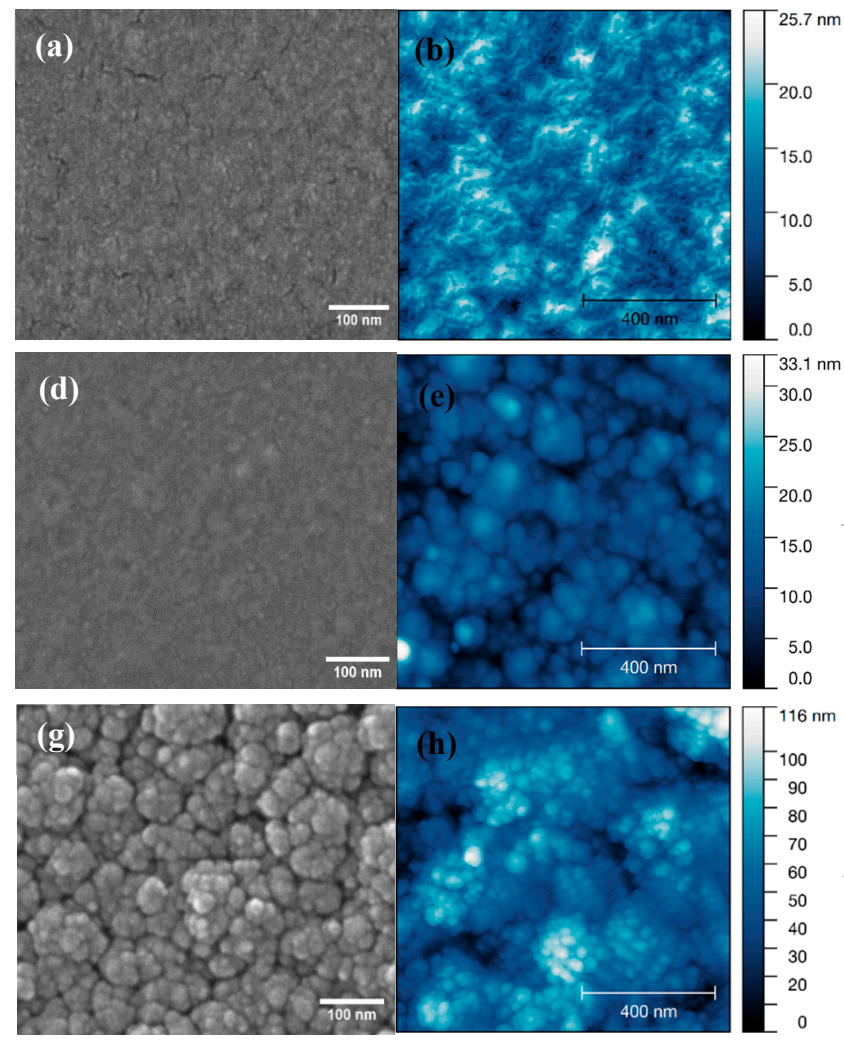

(c)

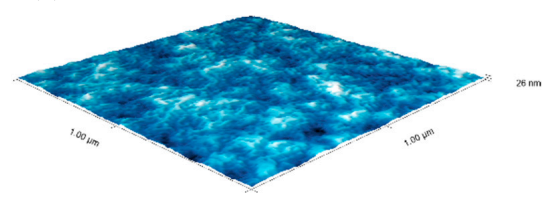

(f)

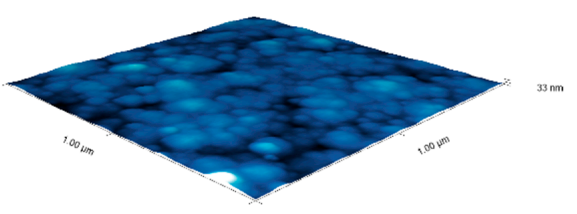

(i)

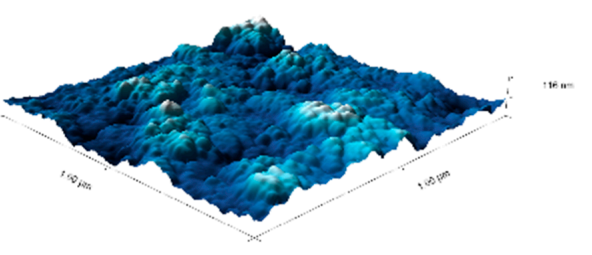

Figure 3. SEM images, AFM scans and 3D images of $\mathrm{Al}_{2} \mathrm{O}_{3}$ films deposited for $24 \mathrm{~h}$ with $150 \mathrm{sccm} \mathrm{Ar}$ gas flow, precursor temperature at $120^{\circ} \mathrm{C}$ and deposition temperature at $(\mathbf{a}-\mathbf{c}) 300^{\circ} \mathrm{C}$; (d-f) $350{ }^{\circ} \mathrm{C}$; (g-i) $400^{\circ} \mathrm{C}$.

\subsection{Pulsed CVD}

After the optimization of CVD parameters, a pulsed CVD process was introduced to identify the minimum duration required for a metal precursor pulse, thereby preventing over-dosing. In order to obtain vapor transport (film growth), the pulse of ATSB was set to $20 \mathrm{~s}$ or $1 \mathrm{~min}$, the deposition temperature was $350{ }^{\circ} \mathrm{C}$ and the precursor temperature was fixed at $120^{\circ} \mathrm{C}$ with an Ar flow rate of $120 \mathrm{sccm}$. Comparing the AFM images of $\mathrm{Al}_{2} \mathrm{O}_{3}$ films deposited via continuous CVD (24 h), pulse CVD ( 1 min ATSB pulse, 1 min Ar purge, 1000 cycles) and pulsed CVD (20 s ATSB pulse, 1 min Ar purge, 1000 cycles). Figure 4 shows the surface roughness decrease from $R_{\mathrm{q}}$ (continuous deposition) $=10.19 \mathrm{~nm}$ to $\mathrm{R}_{\mathrm{q}(1 \mathrm{~min} \text { pulse })}=2.51 \mathrm{~nm}$ and $\mathrm{R}_{\mathrm{q}(20 \mathrm{~s} \text { pulse })}=2.27 \mathrm{~nm}$. We concluded from these data that a $20 \mathrm{~s}$ pulse produced complete coverage and was therefore a suitable starting point for ATSB precursor dosing in an ALD process. 
(a)

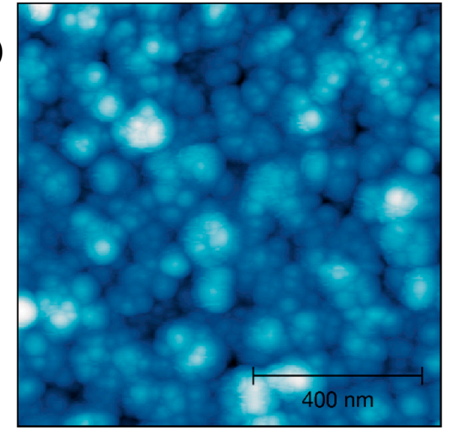

(c)

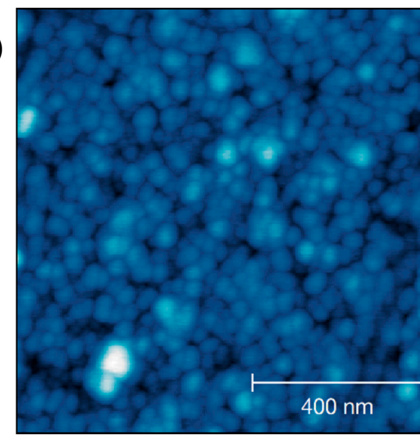

(e)

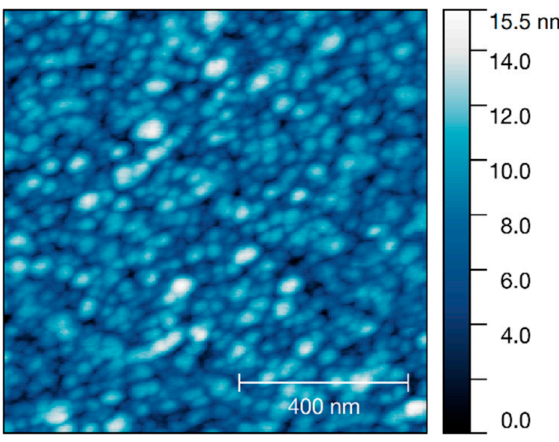

(b)

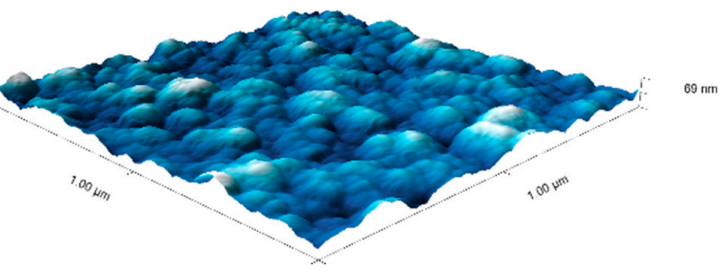

(d)

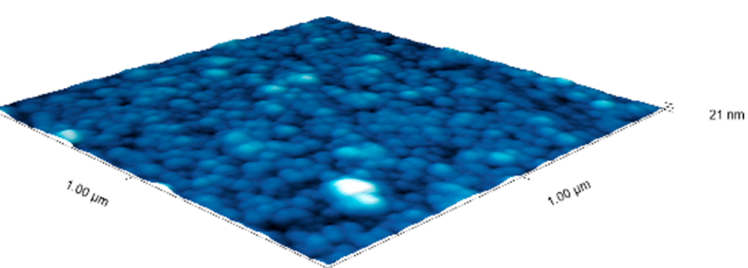

(f)

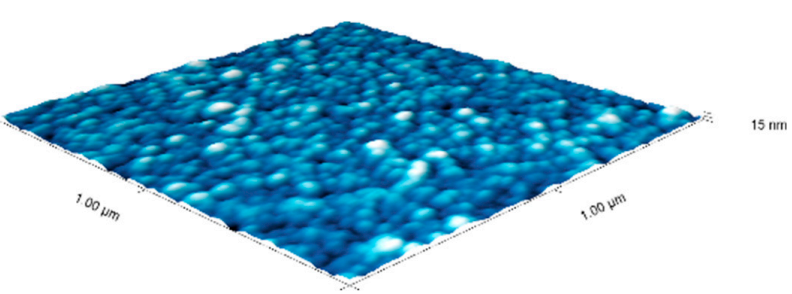

Figure 4. $\mathrm{AFM}$ scans and $3 \mathrm{D}$ images of $\mathrm{Al}_{2} \mathrm{O}_{3}$ films deposited at $350^{\circ} \mathrm{C}$ via $(\mathbf{a}, \mathbf{b})$ continuous CVD; $(\mathbf{c}, \mathbf{d})$ pulsed CVD (1 min ATSB pulse) and (e,f) pulsed CVD (20 s ATSB pulse).

\subsection{Deposition Parameter Optimization for ALD}

The reaction mechanism when using ATSB and water as ALD precursors may be expected as [31,32]:

$$
\begin{gathered}
\mathrm{x}-\mathrm{OH}(\mathrm{s})+\mathrm{Al}\left(\mathrm{O}^{\mathrm{s}} \mathrm{Bu}\right)_{3}(\mathrm{~g}) \rightarrow(-\mathrm{O}-)_{x} \mathrm{Al}\left(\mathrm{O}^{\mathrm{s}} \mathrm{Bu}\right)_{3-x}(\mathrm{~s})+x^{\mathrm{s}} \mathrm{BuOH}(\mathrm{g}) \\
(-\mathrm{O}-)_{x} \mathrm{Al}\left(\mathrm{O}^{\mathrm{s}} \mathrm{Bu}\right)_{3-x}(\mathrm{~s})+(3-x) \mathrm{H}_{2} \mathrm{O}(\mathrm{g}) \rightarrow(-\mathrm{O}-)_{x} \mathrm{Al}(\mathrm{OH})_{3-x}(\mathrm{~s})+(3-x)^{\mathrm{s}} \mathrm{BuOH}(\mathrm{g})
\end{gathered}
$$

with $x=1$ being the monodentate, $x=2$, bidentate and $x=3$, tridentate, respectively, depending on the number of alkoxide ligands.

A full ALD reaction contains two half reactions. In the first half reaction, ATSB reacts with $\mathrm{OH}$ groups on the substrate surface to produce $(-\mathrm{O}-)_{x} \mathrm{Al}\left(\mathrm{O}^{\mathrm{s}} \mathrm{Bu}\right)_{3-x}$, where $\mathrm{x}$ is the number of $\mathrm{OH}$ surface sites react with ATSB which also determines the geometrical configuration on the surface. The $(-\mathrm{O}-)_{x} \mathrm{Al}\left(\mathrm{O}^{\mathrm{s}} \mathrm{Bu}\right)_{3-x}$ group can react with $\mathrm{H}_{2} \mathrm{O}$ to form $(-\mathrm{O}-)_{x} \mathrm{Al}(\mathrm{OH})_{3-x}$ in the second half of the reaction, therefore, the surface layer is covered with $\mathrm{OH}$ groups again, allowing the first half reaction to take place again [33].

The deposition temperature used in ALD should be lower than that used in CVD to avoid uncontrolled CVD-like film growth, therefore the ALD deposition temperature was decreased in comparison to CVD in increments from $350^{\circ} \mathrm{C}$ to $300^{\circ} \mathrm{C}, 250{ }^{\circ} \mathrm{C}$ and $200^{\circ} \mathrm{C}$ whilst the other parameters were kept unchanged (20 s ATSB pulse, $1 \mathrm{~min}$ Ar purge, $2 \mathrm{~s} \mathrm{H}_{2} \mathrm{O}$ pulse and 3 min Ar purge with $120 \mathrm{sccm}$ Ar gas flow deposited for 500 cycles). XPS spectra of this series of samples indicate that films 
deposited at $200{ }^{\circ} \mathrm{C}, 250{ }^{\circ} \mathrm{C}$ and $300^{\circ} \mathrm{C}$ show similar binding energy intensity at approximately $74 \mathrm{eV}$ (Figure 5). The growth rate of $\mathrm{Al}_{2} \mathrm{O}_{3}$ was between 1.9-2.3 nm/cycle in the deposition temperature range of $200{ }^{\circ} \mathrm{C}-300{ }^{\circ} \mathrm{C}$ with a $20 \mathrm{~s}$ pulse time, thus $200{ }^{\circ} \mathrm{C}$ was selected in further experiments (Figure $\mathrm{S} 4)$. The thickness and growth rate were found to be much higher than previously reported values (0.1 nm/cycle) [34-39] indicating a combination of ALD and CVD-like growth. One likely explanation is that the dose time of ATSB was too long for the purge time used, therefore the ATSB dose time was reduced from $20 \mathrm{~s}$ to $2.5 \mathrm{~s}$ with the aim to avoid CVD-like growth. Changing the ATSB purge time from $1 \mathrm{~min}$ to $3 \mathrm{~min}$ reduced the deposition rate, while more than $3 \mathrm{~min}$ for a $2.5 \mathrm{~s}$ dose time resulted in no change in the growth rate, therefore $3 \mathrm{~min}$ purge was considered optimum for a $2.5 \mathrm{~s}$ Similarly, for a $2 \mathrm{~s} \mathrm{H}_{2} \mathrm{O}$ dose, changing the purge time from $3 \mathrm{~min}$ to $5 \mathrm{~min}$ had no effect, indicating that a $3 \mathrm{~min}$ purge was sufficient to ensure all water was evacuated between cycles.

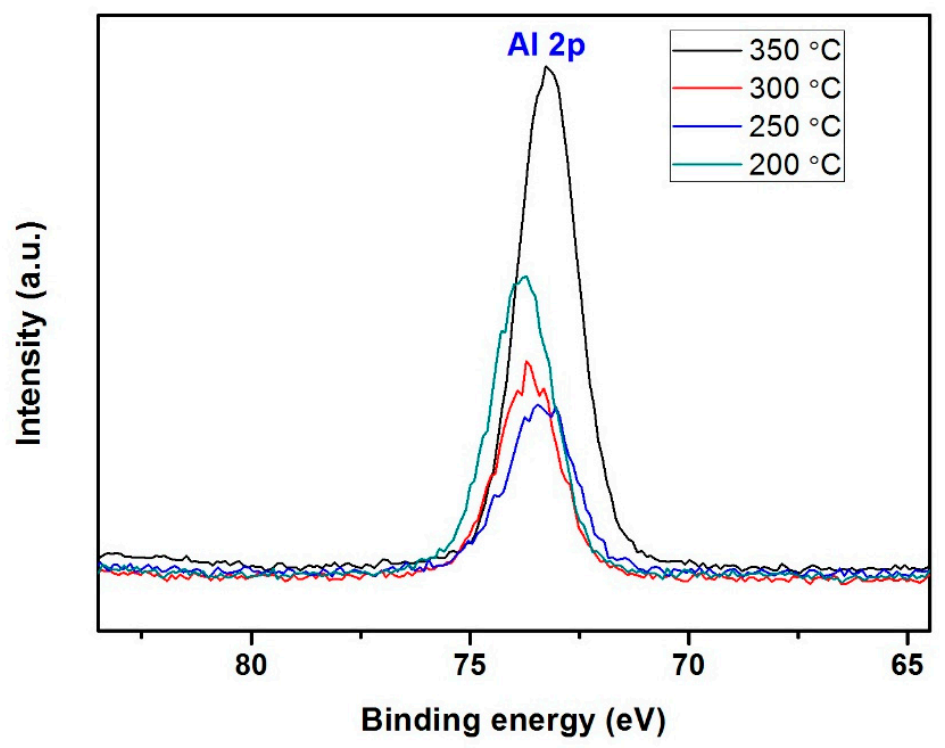

Figure 5. High resolution XPS spectra of Al elements under different deposition temperature, $200{ }^{\circ} \mathrm{C}$, $250{ }^{\circ} \mathrm{C}, 300^{\circ} \mathrm{C}$ and $350{ }^{\circ} \mathrm{C}$.

With a $2.5 \mathrm{~s}$ dose time, the thickness reduced to approx. $50 \mathrm{~nm}$ after 500 cycles, which gave growth rates in the range of 0.12 to $0.15 \mathrm{~nm} /$ cycle with successful deposition on silicon, quartz and glass substrates (Table S1). The growth rate using ATSB as an ALD precursor is similar to that using TMA or $\mathrm{AlCl}_{3}(0.08-0.2 \mathrm{~nm} / \mathrm{cycle})$ [38,40-42]. Thus, the ALD-like parameters were fixed at an ATSB bubbler temperature of $120^{\circ} \mathrm{C}$, deposition temperature of $200{ }^{\circ} \mathrm{C}$ and gas flow rate of $120 \mathrm{sccm}$ (a full cycle includes $2.5 \mathrm{~s}$ ATSB pulse, $3 \mathrm{~min}$ Ar purge, $2 \mathrm{~s} \mathrm{H}_{2} \mathrm{O}$ pulse and $3 \mathrm{~min}$ Ar purge).

The density of the $\mathrm{Al}_{2} \mathrm{O}_{3}$ component in the ellipsometric EMA model varied between 0.720 and 0.757 (Table S1 and Figure S5). The films deposited with short $2.5 \mathrm{~s}$ ATSB pulse times showed lower growth rates $(0.12-0.15 \mathrm{~nm} /$ cycle) and higher densities than those grown with longer $20 \mathrm{~s}$ pulses. The root mean square roughness of $\mathrm{Al}_{2} \mathrm{O}_{3}$ film on three substrates were $\mathrm{R}_{\mathrm{q}(\text { silicon) }}=1.48 \mathrm{~nm}$, $\mathrm{R}_{\mathrm{q} \text { (quartz) }}=1.16 \mathrm{~nm}$ and $\mathrm{R}_{\mathrm{q} \text { (glass) }}=0.96 \mathrm{~nm}$, suggesting an applicability of $\mathrm{Al}_{2} \mathrm{O}_{3}$ on a variety of substrates (Figure 6). 
(a)

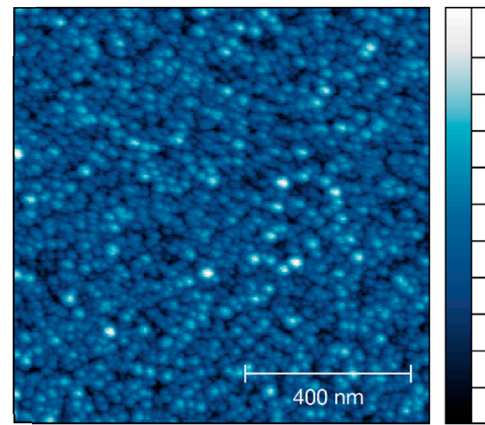

(c)

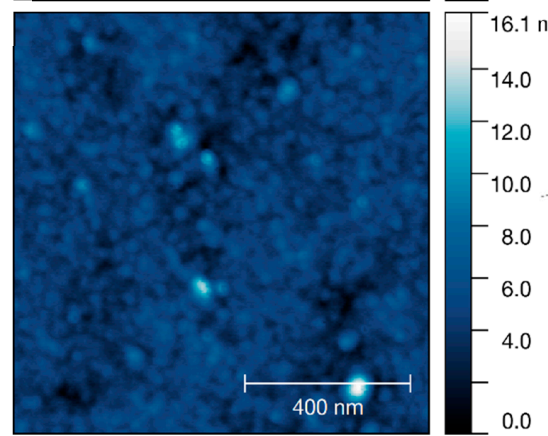

(e)

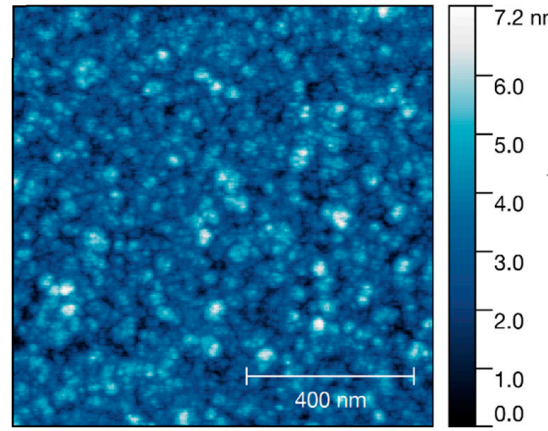

(b)

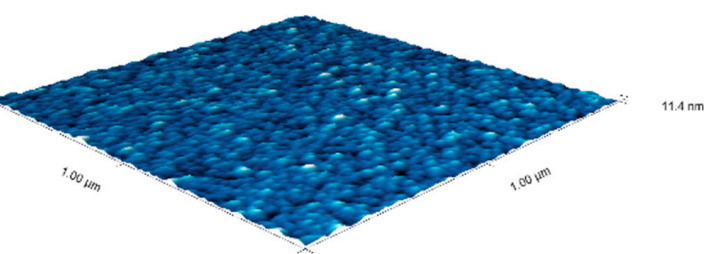

(d)

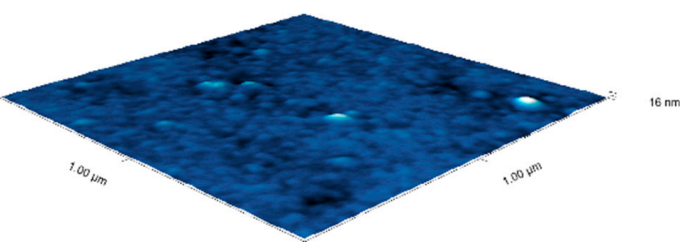

(f)

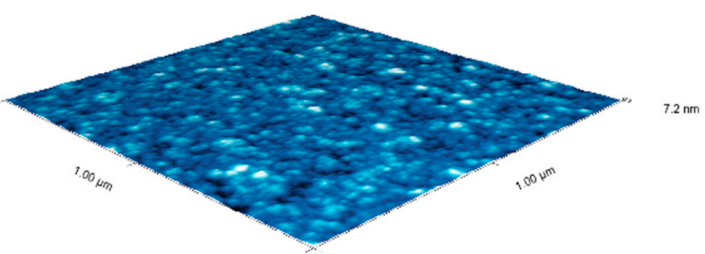

Figure 6. AFM scans and 3D images of $\mathrm{Al}_{2} \mathrm{O}_{3}$ films after $250 \mathrm{ALD}$ cycles, on (a,b) silicon; (c,d) quartz; $(\mathbf{e}, \mathbf{f})$ glass. A cycle includes $2.5 \mathrm{~s}$ ATSB pulse, $3 \mathrm{~min}$ Ar purge, $2 \mathrm{~s} \mathrm{H}_{2} \mathrm{O}$ pulse and $3 \mathrm{~min}$ Ar purge, deposition temperature $200{ }^{\circ} \mathrm{C}$, gas flow rate $120 \mathrm{sccm}$.

\section{4. $\mathrm{ALD} \mathrm{Al}_{2} \mathrm{O}_{3}$ Films on Complex Structured $\mathrm{Au} / \mathrm{WO}_{3}$}

Our aim is to use this $\mathrm{ALD} \mathrm{Al}_{2} \mathrm{O}_{3}$ film as a passivation layer for photoelectrode. In former studies of ALD thin films that include $\mathrm{Al}_{2} \mathrm{O}_{3}$ and other oxides [43-45], it has been mentioned that either an ultrathin film of several nanometers or a thin film with a thickness above $20 \mathrm{~nm}$ showed different degrees of current density enhancement during a photoelectrochemical test.

$\mathrm{Al}_{2} \mathrm{O}_{3}$ films were deposited via the ALD-like process on a complex nanostructure consisting of $\mathrm{Au}$ nanoparticles on needle-like $\mathrm{WO}_{3}$ nanostructures $\left(\mathrm{Au} / \mathrm{WO}_{3}\right.$, Figures 7 and 8). $\mathrm{Au} / \mathrm{WO}_{3}$ is an electrode prepared in house on an FTO glass for water splitting. However, it is not stable in any kind of electrolyte. Therefore, $\mathrm{Al}_{2} \mathrm{O}_{3}$ films were deposited with the aim to protect the electrode without severely affecting the photocurrent required for water splitting. The SEM image of the $\mathrm{Au} / \mathrm{WO}_{3}$ shows a plane of nanoneedles which has a high surface area and high porosity. Due to the complex structure, the thickness of the ALD layer was difficult to measure using an optical method, therefore film thickness during deposition was recorded using a 'witness' planar substrate inserted in the reactor at the same time with the sample. Growth rate as a function of number of cycles was plotted (Figure 8a). The growth rate of $\mathrm{Al}_{2} \mathrm{O}_{3}$ on both the witness plate and the nanostructures was between $0.1 \mathrm{~nm} / \mathrm{cycle}$ and $0.13 \mathrm{~nm} /$ cycle (shown in Figure S6). For a given number of cycles, similar thickness were achieved on both surfaces. There is a strong correlation between the film thickness and the number of ALD cycles (Table 1), e.g., 50 cycles and 300 cycles gave $4 \mathrm{~nm}$ and $40 \mathrm{~nm}$ respectively on both the planar 
substrate (measured using ellipsometry) and the complex nanomaterial architecture (measured by TEM, Figure 8c,d).

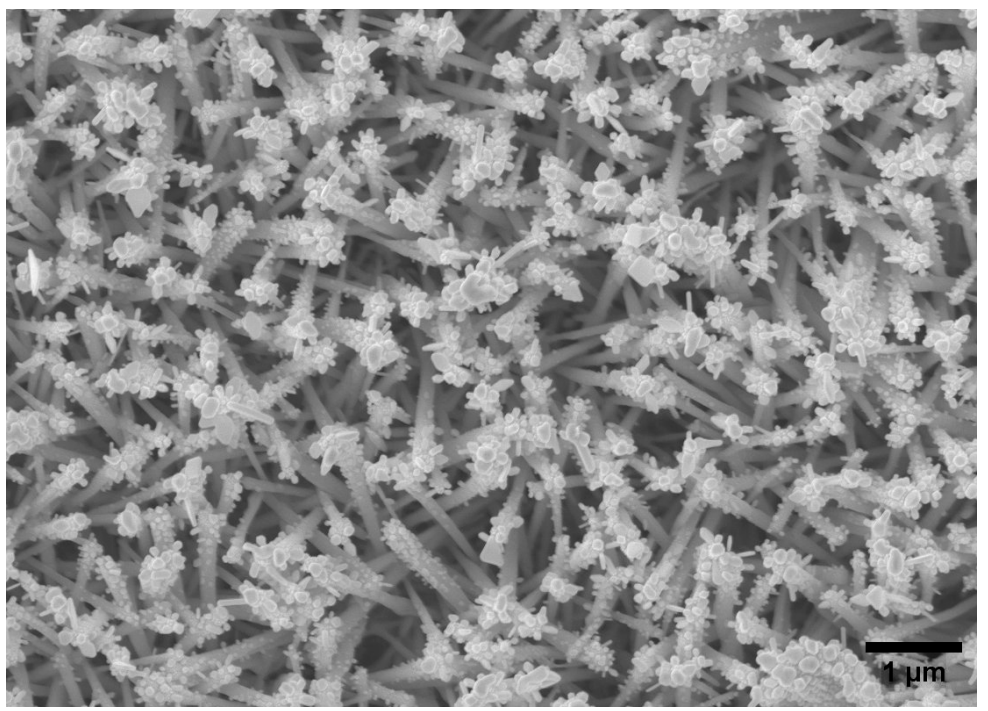

Figure 7. SEM image of $\mathrm{Au} / \mathrm{WO}_{3}$ film deposited via CVD (top view).

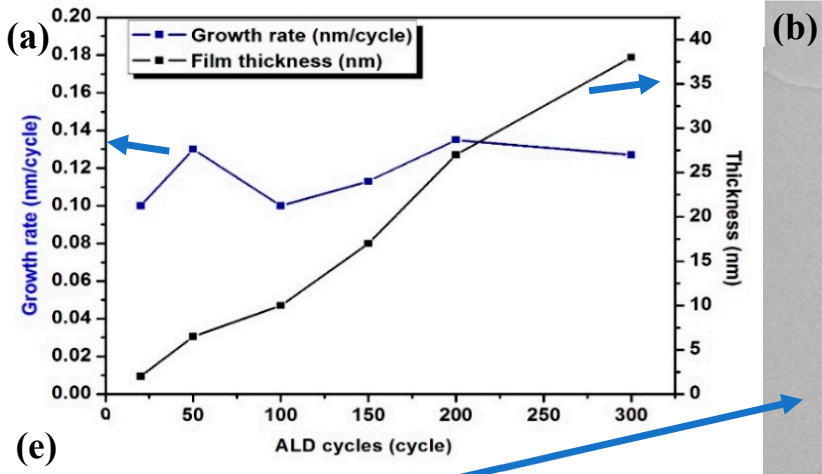

(e) $\mathrm{Au} / \mathrm{WO}_{3}$

(b)
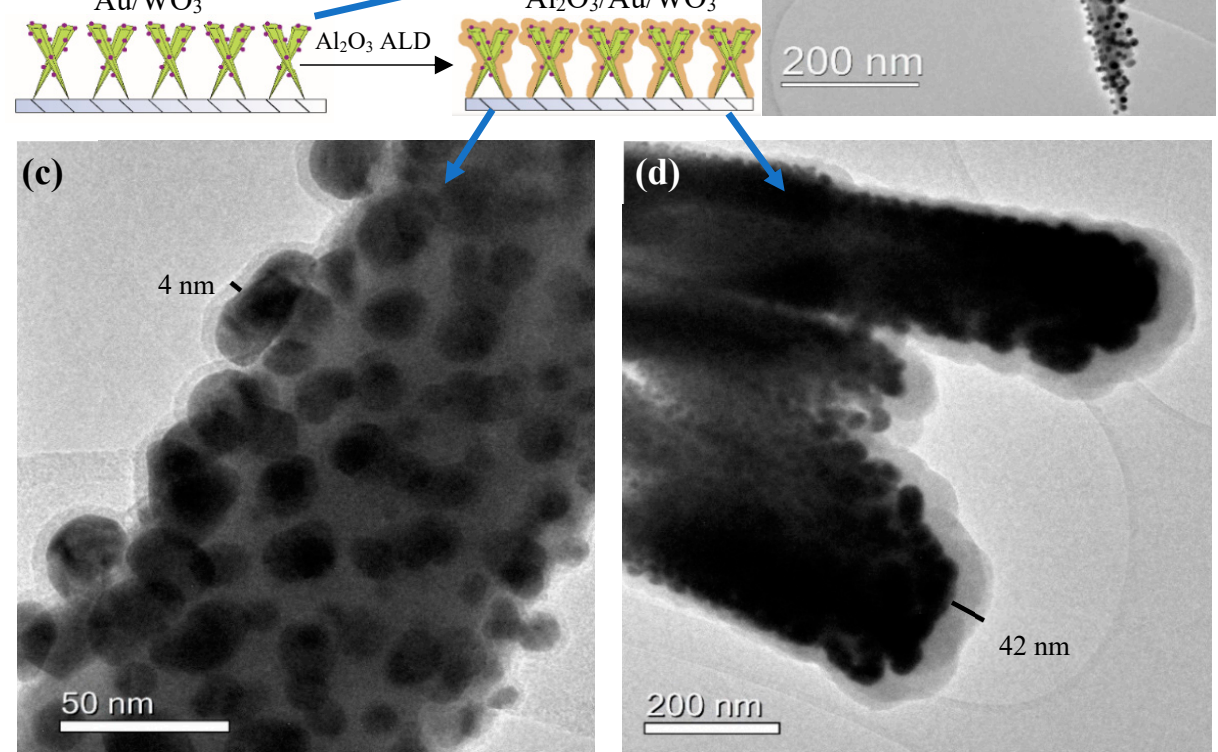

Figure 8. (a) $\mathrm{Al}_{2} \mathrm{O}_{3}$ film growth rate (blue) and film thickness (black) as a function of reaction cycles, (b) $\mathrm{Au} / \mathrm{WO}_{3}$ structure, (c) $\mathrm{Au} / \mathrm{WO}_{3}$ with 50 cycles $\mathrm{ALD} \mathrm{Al}{ }_{2} \mathrm{O}_{3}$ growth on top, (d) $\mathrm{Au} / \mathrm{WO}_{3}$ with 300 cycles $\mathrm{ALD} \mathrm{Al} \mathrm{O}_{3}$ growth on top, (e) Schematic procedure of $\mathrm{ALD} \mathrm{Al}_{2} \mathrm{O}_{3}$ growth. 
Table 1. Summary of the $\mathrm{ALD} \mathrm{Al}_{2} \mathrm{O}_{3}$ thin film deposition parameters and the film thickness on $\mathrm{Au} / \mathrm{WO}_{3}$, FTO and silicon.

\begin{tabular}{|c|c|c|c|c|c|c|c|c|}
\hline \multirow{2}{*}{ Substrate } & \multicolumn{4}{|c|}{ Deposition Recipe } & \multirow{2}{*}{$\begin{array}{c}\text { Cycle } \\
\text { (Number) }\end{array}$} & \multirow{2}{*}{$\begin{array}{c}\text { Substrate } \\
\text { Temperature }\left({ }^{\circ} \mathrm{C}\right)\end{array}$} & \multirow{2}{*}{$\begin{array}{c}\text { Flow Rate } \\
\text { (sccm) }\end{array}$} & \multirow{2}{*}{$\begin{array}{c}\text { Thickness } \\
\text { (nm) }\end{array}$} \\
\hline & ATSB & Purge & $\mathrm{H}_{2} \mathrm{O}$ & Purge & & & & \\
\hline \multirow{6}{*}{$\begin{array}{l}\text { Silicon, } \\
\text { FTO and } \\
\mathrm{Au} / \mathrm{WO}_{3}\end{array}$} & \multirow{6}{*}{$2.5 \mathrm{~s}$} & \multirow{6}{*}{$3 \mathrm{~min}$} & \multirow{6}{*}{$2 \mathrm{~s}$} & \multirow{6}{*}{$3 \mathrm{~min}$} & 20 & \multirow{6}{*}{200} & \multirow{6}{*}{120} & 2 \\
\hline & & & & & 50 & & & 7 \\
\hline & & & & & 100 & & & 10 \\
\hline & & & & & 150 & & & 15 \\
\hline & & & & & 200 & & & 20 \\
\hline & & & & & 300 & & & 40 \\
\hline
\end{tabular}

The XPS spectrum of $\mathrm{Al} 2 \mathrm{p}$ shows that the intensity of $\mathrm{Al} 2 \mathrm{p}$ peak increases with the increase of the number of cycles (Figure 9a). In contrast, the intensity of $\mathrm{Au} 4 \mathrm{f}$ peak decreases with the increase of the number of cycles, with very little $\mathrm{Au} 4 \mathrm{f}$ signal intensity remaining after 50 cycles $\left(\sim 6 \mathrm{~nm} \mathrm{Al}{ }_{2} \mathrm{O}_{3}\right)$ and no $\mathrm{Au}$ signal detected after 150 cycles $\left(\sim 18 \mathrm{~nm}\right.$ ) (Figure 9b). Our interest in the conformal $\mathrm{Al}_{2} \mathrm{O}_{3}$ is as a barrier/corrosion resistant layer for electrochemistry/photoelectrochemistry. To evaluate the quality of the coating, the photoelectrochemical performance was tested (Figure 10). The results demonstrate that increasing the $\mathrm{Al}_{2} \mathrm{O}_{3}$ film thickness beyond 50 deposition cycles $(\sim 6 \mathrm{~nm})$ lead to a significant decrease in photocurrent density, as expected for high dieletric material. Consequently, both the XPS and PEC data indicate that even for a 50 cycles coating, the $\mathrm{Al}_{2} \mathrm{O}_{3}$ film was conformal and without pinholes even on these high aspect ratio, porous nanostructures.
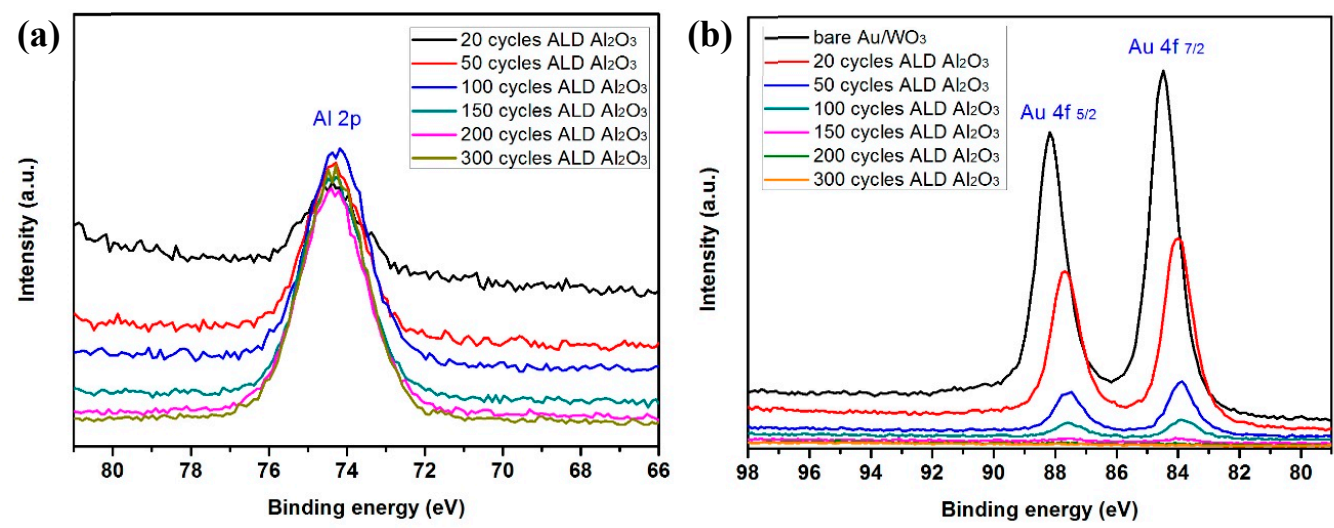

Figure 9. XPS spectra of (a) $\mathrm{Al} 2 \mathrm{p}$ and (b) $\mathrm{Au} 4 \mathrm{f}$ in $\mathrm{Al}_{2} \mathrm{O}_{3} / \mathrm{Au} / \mathrm{WO}_{3}$ nanostructures with various cycles of $\mathrm{ALD} \mathrm{Al}_{2} \mathrm{O}_{3}$ thin film.

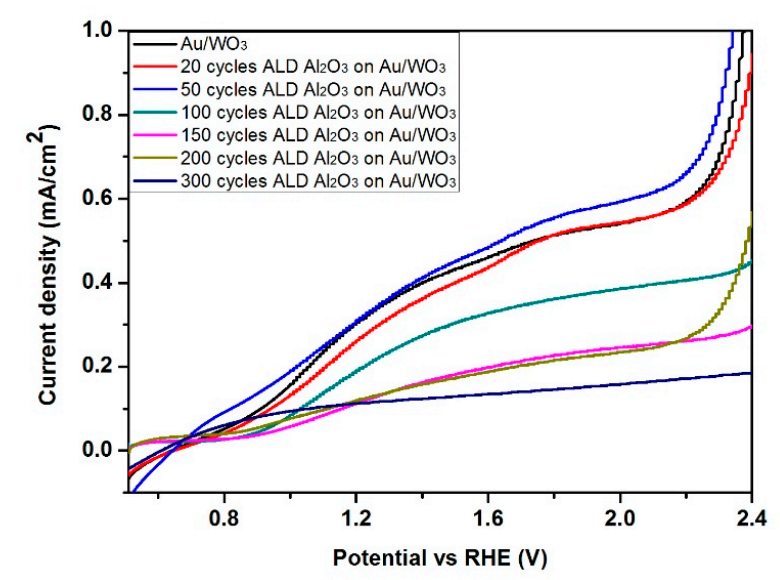

Figure 10. $\mathrm{J}-\mathrm{V}$ curves of $\mathrm{Al}_{2} \mathrm{O}_{3} / \mathrm{Au} / \mathrm{WO}_{3}$ during photoelectrochemical measurement. 


\section{Conclusions}

In the study, the parameters of $\mathrm{Al}_{2} \mathrm{O}_{3}$ thin films atomic layer deposition using aluminum tri-sec-butoxide as a new $\mathrm{Al}$ precursor and water for ALD were investigated. The CVD, pulsed CVD and ALD process was optimized, with the best deposition conditions for ALD as follows: ATSB bubbler temperature $120{ }^{\circ} \mathrm{C}$; deposition temperature $200{ }^{\circ} \mathrm{C}$; gas flow rate $120 \mathrm{sccm}$; ATSB pulse time $2.5 \mathrm{~s}$; Ar purge time $3 \mathrm{~min} ; \mathrm{H}_{2} \mathrm{O}$ pulse time $2 \mathrm{~s}$; Ar purge time $3 \mathrm{~min}$. A stable ALD process with a growth rate of $0.12-0.15 \mathrm{~nm} /$ cycle was observed by measuring the $\mathrm{Al}_{2} \mathrm{O}_{3}$ film thickness on different substrates using ellipsometry. The composition and morphology of the as-synthesized films were analyzed and followed by the comparison of film deposition under different conditions. SEM, AFM and XPS data indicated that the obtained films were dense and continuous with a low concentration of impurities. TEM images of $\mathrm{Al}_{2} \mathrm{O}_{3}$ thin films prepared from ATSB and water on complex nanostructures show uniformity, conformality and good control of thickness, strongly suggesting the potential of using this new ALD precursor for $\mathrm{Al}_{2} \mathrm{O}_{3}$ thin films. These $\mathrm{Al}_{2} \mathrm{O}_{3}$ films are likely to be used as a protection layer on the $\mathrm{Au} / \mathrm{WO}_{3}$ electrode for photoelectrochemical water splitting.

Supplementary Materials: The following are available online at http:/www.mdpi.com/1996-1944/12/9/1429/s1, Figure S1: The relationship between ATSB vapor pressure and ATSB precursor temperature. Figure S2: XRD pattern of $\mathrm{Al}_{2} \mathrm{O}_{3}$ film deposited via CVD. This example was made under condition: precursor temperature $120^{\circ} \mathrm{C}$; deposition temperature $350^{\circ} \mathrm{C}$; gas flow rate $150 \mathrm{sccm}$; deposition time $24 \mathrm{~h}$. Figure S3: Raman spectra of $\mathrm{Al}_{2} \mathrm{O}_{3}$ film deposited via CVD. This example was made under condition: precursor temperature $120^{\circ} \mathrm{C}$; deposition temperature $350{ }^{\circ} \mathrm{C}$; gas flow rate $150 \mathrm{sccm}$; deposition time $24 \mathrm{~h}$. Figure S4: Growth rates of the $\mathrm{Al}_{2} \mathrm{O}_{3}$ films as a function of deposition temperature from $200^{\circ} \mathrm{C}$ to $300^{\circ} \mathrm{C}$ established via ellipsometry. The deposition conditions were $20 \mathrm{~s}$ ATSB pulse, 1 min Ar purge, $2 \mathrm{~s} \mathrm{H}_{2} \mathrm{O}$ pulse and $3 \mathrm{~min}$ Ar pulse for 500 cycles. Figure S5: Refractive index of (a) $\mathrm{Al}_{2} \mathrm{O}_{3}$ [23], and (b) $\mathrm{Al}_{2} \mathrm{O}_{3} /$ air (0.757/0.243) Effective Medium Approximation used for ellipsometric modelling of ALD film on glass, Figure 6e. Figure S6: Film thicknesses established via Ellipsometry for ALD growth on Silicon samples ( $R^{2}$ fit quality for each ellipsometric fitting labelled). EMA concentration for all samples held at $74.5 \%$. ATSB pulse duration $2.5 \mathrm{~s}$. Table S1: Table of structural parameters from for ellipsometric model fitting between (1.25-5 eV) for samples produced via ALD ( 250 cycles: ATSB pulse indicated, 3 min purge, $2 \mathrm{~s}$ $\mathrm{H}_{2} \mathrm{O}$ pulse, 3 min purge).

Author Contributions: Conceptualization, X.X. and C.B.; Data curation, X.X.; Formal analysis, X.X., A.T.; Funding acquisition, C.B.; Methodology, X.X. and S.G.; Project administration, C.B. and S.G.; Resources, X.X., A.T., S.G. and C.B.; Software, X.X., A.T. and Y.Z.; Supervision, C.B. and S.G.; Visualization, X.X. and Y.Z.; Writing -original draft, X.X.; Writing—review \& editing, X.X., S.G., A.T., Y.Z. and C.B.

Funding: This research received no external funding.

Acknowledgments: The authors gratefully acknowledge the support by Department of Chemistry, University College London and China Scholarship Council. The authors would also like to acknowledge support from Rachel Wilson, Yaomin Li, Steven Firth, Robert Palgrave and Steve Hudziak.

Conflicts of Interest: The authors declare no conflict of interest.

\section{References}

1. Bordihn, S.; Engelhart, P.; Mertens, V.; Kesser, G. High surface passivation quality and thermal stability of $\mathrm{ALD} \mathrm{Al}_{2} \mathrm{O}_{3}$ on wet chemical grown ultra-thin $\mathrm{SiO}_{2}$ on silicon. Energy Procedia 2011, 8, 654-659. [CrossRef]

2. Dingemans, G.; Seguin, R.; Engelhart, P.; Van De Sanden, M.C.M.; Kessels, W.M.M. Silicon surface passivation by ultrathin $\mathrm{Al}_{2} \mathrm{O}_{3}$ films synthesized by thermal and plasma atomic layer deposition. Phys. Status Solidi (RRL) 2010, 4, 10-12. [CrossRef]

3. Tang, S.H.; Kuo, C.I.; Trinh, H.D.; Hudait, M.; Chang, E.Y.; Hsu, C.Y.; Su, Y.H.; Luo, G.L.; Nguyen, H.Q. C-V characteristics of epitaxial germanium metal-oxide-semiconductor capacitor on GaAs substrate with ALD $\mathrm{Al}_{2} \mathrm{O}_{3}$ dielectric. Microelectron. Eng. 2012, 97, 16-19. [CrossRef]

4. Ritala, M.; Leskela, M.; Dekker, J.-P.; Mutsaers, C.; Soininen, P.J.; Skarp, J. Perfectly conformal TiN and $\mathrm{Al}_{2} \mathrm{O}_{3}$ films deposited by atomic layer deposition. Chem. Vap. Depos. 1999, 5, 7-9. [CrossRef]

5. Schmidt, J.; Merkle, A.; Brendel, R.; Hoex, B.; Van De Sanden, M.C.M.; Kessels, W.M.M. Surface passivation of high-efficiency silicon solar cells by atomic-layer-deposited $\mathrm{Al}_{2} \mathrm{O}_{3}$. Prog. Photovoltaics Res. Appl. 2008, 16, 461-466. [CrossRef] 
6. Siol, S.; Hellmann, J.C.; Tilley, S.D.; Graetzel, M.; Morasch, J.; Deuermeier, J.; Jaegermann, W.; Klein, A. Band alignment engineering at $\mathrm{Cu}_{2} \mathrm{O} / \mathrm{ZnO}$ heterointerfaces. ACS Appl. Mater. Interfaces 2016, 8, 21824-21831. [CrossRef] [PubMed]

7. García-valenzuela, J.A.; Rivera, R.; Morales-vilches, A.B.; Gerling, L.G.; Caballero, A.; Asensi, J.M.; Voz, C.; Bertomeu, J.; Andreu, J. Main properties of $\mathrm{Al}_{2} \mathrm{O}_{3}$ thin fi lms deposited by magnetron sputtering of an $\mathrm{Al}_{2} \mathrm{O}_{3}$ ceramic target at different radio-frequency power and argon pressure and their passivation effect on p-type c-Si wafers. Thin Solid Films 2016, 619, 288-296. [CrossRef]

8. Hoffman, D.; Leibowitz, D. $\mathrm{Al}_{2} \mathrm{O}_{3}$ films prepared by electron-beam evaporation of hot-pressed $\mathrm{Al}_{2} \mathrm{O}_{3}$ in oxygen ambient. J. Vac. Sci. Technol. 1971, 8, 107-111. [CrossRef]

9. Landälv, L. Thin film and plasma characterization of PVD oxides. Ph.D. Thesis, Linköping University, Linköping, Sweden, 2017.

10. Mcclure, C.D.; Oldham, C.J.; Parsons, G.N. Surface \& coatings technology effect of $\mathrm{Al}_{2} \mathrm{O}_{3}$ ALD coating and vapor infusion on the bulk mechanical response of elastic and viscoelastic polymers. Surf. Coat. Technol. 2015, 261, 411-417. [CrossRef]

11. Yang, P.; Yao, M.; Xiao, R.; Chen, J.; Yao, X. Preparation of $\mathrm{Al}_{2} \mathrm{O}_{3}$ film by sol-gel method on thermally evaporated Al film. Vacuum 2014, 107, 112-115. [CrossRef]

12. George, S.M. Atomic layer deposition: an overview. Chem. Rev. 2009, 110, 111-131. [CrossRef] [PubMed]

13. Puurunen, R.L. A short history of atomic layer deposition: Tuomo Suntola's atomic layer epitaxy. Chem. Vapor Depos. 2014, 20, 332-344. [CrossRef]

14. Jones, A.C.; Hitchman, M.L. Chemical Vapour Deposition: Precursors, Processes and Applications; Royal Society of Chemistry: Cambridge, UK, 2009.

15. Johnson, R.W.; Hultqvist, A.; Bent, S.F. A brief review of atomic layer deposition: from fundamentals to applications. Mater. Today 2014, 17, 236-246. [CrossRef]

16. Multone, X.; Hoffmann, P. High Vacuum Chemical Vapor Deposition (HV-CVD) of Alumina Thin Films; École polytechnique fédérale de Lausanne: Lausanne, Switzerland, 2009.

17. Muhsin, A.E. Chemical vapor deposition of aluminum oxide $\left(\mathrm{Al}_{2} \mathrm{O}_{3}\right)$ and beta iron disilicide $\left(\beta-\mathrm{FeSi}_{2}\right)$ thin films. Ph.D. Thesis, University of Duisburg-Essen, Duisburg, Germany, 2007.

18. Liu, X.; Chan, S.H.; Wu, F.; Li, Y.; Keller, S.; Speck, J.S.; Mishra, U.K. Metalorganic chemical vapor deposition of $\mathrm{Al}_{2} \mathrm{O}_{3}$ using trimethylaluminum and $\mathrm{O}_{2}$ precursors: growth mechanism and crystallinity. J. Cryst. Growth. 2014, 408, 78-84. [CrossRef]

19. Blittersdorf, B.S.; Bahlawane, N.; Kohse-höinghaus, K.; Atakan, B.; Müller, J. CVD of $\mathrm{Al}_{2} \mathrm{O}_{3}$ Thin films using aluminum tri-isopropoxide. Chem. Vap. Depos. 2003, 4, 194-198. [CrossRef]

20. Ponja, S.D.; Parkin, I.P.; Carmalt, C.J. Synthesis and material characterization of amorphous and crystalline $(\alpha-) \mathrm{Al}_{2} \mathrm{O}_{3}$ via aerosol assisted chemical vapour deposition. RSC Adv. 2016, 6, 102956-102960. [CrossRef]

21. Haanappel, V.A.; Van Corbach, H.D.; Fransen, T.; Gellings, P.J. The pyrolytic decomposition of aluminium-tri-sec-butoxide during chemical vapour deposition of thin alumina films. Thermochim. Acta. 1994, 240, 67-77. [CrossRef]

22. Tompkins, H.G.; Irene, E.A. (Eds.) Handbook of Ellipsometry; Irene Publisher Springer: New York, NY, USA, 2010.

23. Palik, E.D. Handbook of Optical Constants of Solids; Academic Press: Palm Bay, FL, USA, 1997.

24. Aluminium tri-sec-butoxide(2269-22-9) MSDS Melting Point Boiling Point Density Storage Transport. Available online: http://www.chemicalbook.com/ProductMSDSDetailCB5397907_EN.htm (accessed on 13 January 2018).

25. Aluminium tri-sec-butoxide SAFETY DATA SHEET. Available online: https://www.fishersci.com/shop/ msdsproxy?productName=AC191215000\&productDescription=ALUMINUM+TRI-SEC-BUTOXID+ 500GR\&catNo=AC191215000\&vendorId=VN00032119\&storeId=10 (accessed on 13 January 2018).

26. Wilson, R.; Simion, C.; Blackman, C.; Carmalt, C.; Stanoiu, A.; Di Maggio, F.; Covington, J. The effect of film thickness on the gas sensing properties of ultra-thin $\mathrm{TiO}_{2}$ films deposited by atomic layer deposition. Sensors 2018, 18, 735. [CrossRef]

27. Sathyaseelan, B.; Baskaran, I.; Sivakumar, K. Phase transition behavior of nanocrystalline $\mathrm{Al}_{2} \mathrm{O}_{3}$ powders. Soft Nanosci. Let. 2013, 3, 69. [CrossRef]

28. Prokes, S.M.; Katz, M.B.; Twigg, M.E. Growth of crystalline $\mathrm{Al}_{2} \mathrm{O}_{3}$ via thermal atomic layer deposition: nanomaterial phase stabilization. APL Mater. 2014, 2, 032105. [CrossRef] 
29. Cava, S.; Tebcherani, S.M.; Souza, I.A.; Pianaro, S.A.; Paskocimas, C.A.; Longo, E.; Varela, J.A. Structural characterization of phase transition of $\mathrm{Al}_{2} \mathrm{O}_{3}$ nanopowders obtained by polymeric precursor method. Mater. Chem. Phys. 2007, 103, 394-399. [CrossRef]

30. NIST XPS Database Detail Page. Available online: https://srdata.nist.gov/xps/XPSDetailPage.aspx? AllDataNo=67580 (accessed on 15 January 2018).

31. Guerra-Nuñez, C.; Döbeli, M.; Michler, J.; Utke, I. Reaction and growth mechanisms in $\mathrm{Al}_{2} \mathrm{O}_{3}$ deposited via atomic layer deposition: elucidating the hydrogen source. Chem. Mater. 2017, 29, 8690-8703. [CrossRef]

32. Juppo, M.; Rahtu, A.; Ritala, M.; Leskelä, M. In situ mass spectrometry study on surface reactions in atomic layer deposition of $\mathrm{Al}_{2} \mathrm{O}_{3}$ thin films from trimethylaluminum and water. Langmuir 2000, 16, 4034-4039. [CrossRef]

33. Matero, R.; Rahtu, A.; Ritala, M.; Leskelä, M.; Sajavaara, T. Effect of water dose on the atomic layer deposition rate of oxide thin films. Thin Solid Films 2000, 368, 1-7. [CrossRef]

34. Barbos, C.; Blanc-pelissier, D.; Fave, A.; Balnquet, E.; Crisci, A.; Fourmond, E.; Albertini, D.; Sabac, A.; Ayadi, K.; Girard, P.; Lemiti, M. Characterization of $\mathrm{Al}_{2} \mathrm{O}_{3}$ thin films prepared by thermal ALD. Energy Procedia 2015, 77, 558-564. [CrossRef]

35. Barbos, C.; Blanc-pelissier, D.; Fave, A.; Botella, C.; Regreny, P.; Grenet, G.; Blanquet, E.; Crisci, A.; Lemiti, M. $\mathrm{Al}_{2} \mathrm{O}_{3}$ thin films deposited by thermal atomic layer deposition: characterization for photovoltaic applications. Thin Solid Films 2016, 617, 108-113. [CrossRef]

36. Batra, N.; Gope, J.; Panigrahi, J.; Singh, R.; Singh, P.K. Influence of deposition temperature of thermal ALD deposited $\mathrm{Al}_{2} \mathrm{O}_{3}$ films on silicon surface passivation. Aip Adv. 2015, 5, 067113. [CrossRef]

37. Campabadal, F.; Beldarrain, O.; Zabala, M.; Acero, M.C.; Rafí, J.M. Comparison between $\mathrm{Al}_{2} \mathrm{O}_{3}$ thin films grown by ALD using $\mathrm{H}_{2} \mathrm{O}$ or $\mathrm{O}_{3}$ as oxidant source. In Proceedings of the 8th Spanish Conference on Electron Devices, Palma de Mallorca, Spain, 8-11 February 2011.

38. Groner, M.D.; Fabreguette, F.H.; Elam, J.W.; George, S.M. Low-temperature $\mathrm{Al}_{2} \mathrm{O}_{3}$ atomic layer deposition. Chem. Mater. 2004, 16, 639-645. [CrossRef]

39. Vähä-nissi, M.; Sievänen, J.; Salo, E.; Heikkilä, P.; Kenttä, E.; Johansson, L.-S.; Koskinen, J.T.; Harlin, A. Atomic and molecular layer deposition for surface modification. J. Solid State Chem. 2014, 214, 7-11. [CrossRef]

40. Räisänen, P.I.; Ritala, M.; Leskelä, M. Atomic layer deposition of $\mathrm{Al}_{2} \mathrm{O}_{3}$ films using $\mathrm{AlCl}_{3}$ and $\mathrm{Al}\left(\mathrm{O}^{\mathrm{i}} \mathrm{Pr}\right)_{3}$ as precursors. J. Mater. Chem. 2002, 12, 1415-1418. [CrossRef]

41. Kim, J.W.; Kim, D.H.; Oh, D.Y.; Lee, H.; Kim, J.H.; Lee, J.H.; Jung, Y.S. Surface chemistry of $\operatorname{LiN}_{\mathrm{i} 0.5} \mathrm{Mn}_{1.5} \mathrm{O}_{4}$ particles coated by $\mathrm{Al}_{2} \mathrm{O}_{3}$ using atomic layer deposition for lithium-ion batteries. J. Power Sources 2015, 274, 1254-1262. [CrossRef]

42. Iatsunskyi, I.; Kempiński, M.; Jancelewicz, M.; Załęski, K.; Jurga, S.; Smyntyna, V. Structural and XPS characterization of ALD $\mathrm{Al}_{2} \mathrm{O}_{3}$ coated porous silicon. Vacuum 2015, 113, 52-58. [CrossRef]

43. Paracchino, A.; Mathews, N.; Hisatomi, T.; Stefik, M.; Tilley, S.D.; Grätzel, M. Ultrathin films on copper (I) oxide water splitting photocathodes: a study on performance and stability. Energy Environ. Sci. 2012, 5, 8673-8681. [CrossRef]

44. Abdulagatov, A.I.; Yan, Y.; Cooper, J.R.; Zhang, Y.; Gibbs, Z.M.; Cavanagh, A.S.; George, S.M. $\mathrm{Al}_{2} \mathrm{O}_{3}$ and $\mathrm{TiO}_{2}$ atomic layer deposition on copper for water corrosion resistance. ACS Appl. Mater. Interfaces 2011, 3, 4593-4601. [CrossRef]

45. Le Formal, F.; Tetreault, N.; Cornuz, M.; Moehl, T.; Grätzel, M.; Sivula, K. Passivating surface states on water splitting hematite photoanodes with alumina overlayers. Chem. Sci. 2011, 2, 737-743. [CrossRef]

(C) 2019 by the authors. Licensee MDPI, Basel, Switzerland. This article is an open access article distributed under the terms and conditions of the Creative Commons Attribution (CC BY) license (http://creativecommons.org/licenses/by/4.0/). 